\title{
Corporate Social Responsibility and Brand Equity in Mexican Small
}

\section{Firms}

\author{
Gonzalo Maldonado-Guzman ${ }^{1}$, Sandra Yesenia Pinzón-Castro ${ }^{1}, \&$ Lucero Jazmín Cuevas-Pichardo ${ }^{2}$ \\ ${ }^{1}$ Centro de Ciencias Económicas y Administrativas, Universidad Autonoma de Aguascalientes, Mexico \\ ${ }^{2}$ MBA Student, Centro de Ciencias Económicas y Administrativas, Universidad Autónoma de Aguascalientes, \\ México \\ Correspondence: Gonzalo Maldonado-Guzman, Centro de Ciencias Económicas y Administrativas, Universidad \\ Autonoma de Aguascalientes, Aguascalientes, Mexico, Avenida Universidad No. 940, Ciudad Universitaria, C.P. \\ 20131, México.
}

Received: October 18, 2019

Accepted: November 11, $2019 \quad$ Online Published: November 14, 2019

doi:10.5539/ibr.v13n1p18

URL: https://doi.org/10.5539/ibr.v13n1p18

\begin{abstract}
Corporate social responsibility is a topic that has generally been analyzed and discussed in large national and transnational companies, and relatively few studies have been oriented in small and medium-sized enterprises, even though theoretical and empirical evidence has been provided that small businesses also carry out social responsibility activities. Likewise, brand equity has been scarcely related to corporate social responsibility, and there are few studies published in the current marketing literature that relate these two important constructs. Therefore, using a sample of 300 small firms and applying a structural equations model of second order, which allows to know in greater depth the relationship between corporate social responsibility and brand equity, the essential objective of this empirical study is the analysis and discussion of the effects of corporate social responsibility on the level of brand equity of small firms. The results obtained show that corporate social responsibility has a significant positive effect on the level of brand equity of small firms.
\end{abstract}

Keywords: brand, brand equity, innovation, service innovation, small firms

\section{Introduction}

The consumer's preference in the acquisition of a certain brand of a product or service intervenes in an integral way in the success of the businesses, mainly of the small firms, in a highly competitive and globalized market (Oliver, 1999; Kotler \& Armstrong, 2010; Orel \& Kara, 2014). Also, several studies published in the marketing literature, have analyzed various factors that motivate consumers to prefer the brand of products or services of a particular company (Park et al., 2017), finding that corporate social responsibility (CSR) activities are one of the most important factors that positively affect not only consumer preference but also the significant increase in the number of consumers (Liu et al., 2011).

Similarly, there are other studies that have analyzed and discussed the effects of CSR on the brand of products or services as a business strategy (Ellen et al., 2006; Porter \& Kramer, 2006: Du et al., 2007; Husted \& Allen, 2007; Bigné et al., 2009; Torelli et al., 2012; Moosmayer \& Fuljahn, 2013; Pérez \& Rodríguez, 2015), finding positive results. Other studies more published in the marketing literature, have provided theoretical and empirical evidence that show that the firms that adopted and implemented CSR activities, obtained a greater preference in the acquisition of the brand of their products or services, than those companies that are not recognized by consumers as socially responsible (Hamlin \& Wilson, 2004; Pracejus \& Olsen, 2004; Lefferty, 2007; Bigné et al., 2012; Samu \& Wymer, 2014; Wang \& Korschun, 2015).

In this sense, Moosmayer and Fuljahn (2013) found that the various social causes adopted by firms and that are closely related to marketing activities, are commonly better evaluated by consumers, since companies, particularly small firms, perform various activities to motivate their consumers to improve the altruistic perception of their products or services. In a more recent study, Baalbaki and Guzman (2016) identified that CSR activities have significant positive effects on the brand equity of the firm's products or services. However, all the studies mentioned above, except for the study conducted by Bigné et al. (2012), have evaluated the relationship between CSR activities and the brand as a one-dimensional construct, so it is necessary to analyze CSR activities 
as a multidimensional construct (Guzman \& Davies, 2017).

Additionally, both Aaker and Joachimsthaler (2000) and Nan and Heo (2007) proposed that researchers, academics and professionals in the field of marketing, should guide their theoretical and empirical research in analyzing the effects between the various CSR activities and different types of brand, including brand equity. Under this context and given that the studies published in the current marketing literature that analyze the relationship between CSR activities and brand equity are relatively scarce, the main contribution of this empirical study is the analysis and discussion of the different activities CSR in the brand equity of the products or services of small firms in an emerging economy country, as is the case in Mexico, as recommended by Nan and Heo (2007) and Guzman and Davies (2017).

\section{Method}

Recent studies in the field of marketing have found a strong positive relationship between the moral and ethical identity of consumers and CSR activities (Vitell et al., 2016), therefore, it should not be surprising that companies of all sizes and sectors generally seek to adopt and implement CSR activities, with the aim of increasing the reputation and brand image of their products or services (Xie et al., 2019). Therefore, CSR actions developed by companies, including small firms, can be considered as an ethical relationship between marketing practices (Xie et al., 2019), since, according to Malhotra and Agarwal (2017), marketing practices have a high influence on the moral identity of consumers, on the preference of a particular brand, on their emotions, on judgments and, subsequently, on a best consumer-brand relationship.

In addition, some recent studies have focused on analyzing the influence of CSR activities on consumer reactions, through the evaluation of purchasing processes (Sen et al., 2016). Other studies have examined that relate CSR activities and consumer reactions, as is the case of the study conducted by Peloza and Shang (2011), who found that only 73 of 165 published articles related the activities of CSR with the brand, and 52 with the emotions of consumption. Therefore, emotions such as attitudes and gratitude (Romani et al., 2013; Romani \& Grappi, 2014; Xie et al., 2015), and the pride (Kim \& Johnson, 2013), they are considered as the essential variables that positively affect the reactions of consumers to brands of products or services of companies (Xie et al., 2019).

In this sense, CSR activities are commonly considered in the marketing literature, as one of the essential activities of the firms (Berger et al., 2007), not only because they generate a high return on investment (Sen et al., 2006), but also a greater promotion of their products or services by word of mouth (Du et al., 2007), the willingness of consumers to pay a higher price (Trudel \& Cotte, 2008), consumer preference for the brand (Sen \& Bhattacharya, 2001; Lichtenstein et al., 2004), and a significant increase in the brand equity of both the company as of its products or services (Guzman \& Davies, 2017). Therefore, it is feasible to consider that the brand equity of the products or services will depend on a high percentage of the various CSR actions that companies adopt and implement (Wang \& Korschun, 2015).

Thus, brand equity has generally been analyzed and discussed in current marketing literature from the perspective of consumers, business and financing (Keller \& Lehmann, 2006; Baalbaki \& Guzman, 2016; Chatzipanagiotou et al., 2016), However, recently some researchers and scholars have focused their research on the discussion of brand equity in CSR activities (Grönroos \& Voima, 2013; Gyrd-Jones \& Kornum, 2013; Vallester \& von Wallpach, 2013; Iglesias et al., 2013; Kennedy \& Guzman, 2016), even though there were already some published studies that had provided theoretical and empirical evidence, that consumer attitudes have a strong influence on brand preference (Bass \& Wilkie, 1973).

Additionally, some researchers and academics have found that CSR also improves the ethical behavior of employees and workers, which leads to an increase in the efficiency of the organization (Laczniak \& Murphy, 1991; Sims \& Kroeck, 1994; Preston \& O'Bannon, 1997). This is feasible, if we consider that Lussier (2000) and Farrell and Geoffrey (2000), define CSR as "a corporate behavior in relation to business ethics that includes obligations and commitments of companies with society". Therefore, CSR is considered today as both an extension of the ethics and morality of companies (Daft, 2003; Vogel, 2004), as well as their philanthropic responsibility (Stanaland et al., 2011). Therefore, compliance with philanthropic liability obligations will have positive effects not only on business performance, but also on the brand equity of the firms (Maignan et al., 2005). Thus, considering the information presented above, it is possible to propose the first research hypothesis.

H1: The higher level of economic responsibility, higher level of brand equity

On the other hand, in a recent study Torres et al. (2012) concluded that the different social responsibility activities carried out by companies, also positively affect the brand equity of their products or services, understanding as brand equity the preference that consumers have of a particular brand of the total of existing 
brands in the market (Cifci et al., 2016). Therefore, CSR facilitates not only a differentiation of the brand of products or services of organizations, but also the social perception of a higher brand equity (Aaker, 1991). In addition, CSR activities, particularly of small firms, are associated with their value system (Turban \& Greening, 1997), and with their organizational culture (Chappell, 1993), because they generally support the social welfare of the community where they are located the company (Kotler \& Lee, 2004).

In this sense, many of the values of small firms are similar to the values of consumers, which facilitate the identification of such companies as socially responsible (Sen \& Bhattacharya, 2001; Bhattacharya \& Sen, 2003). Therefore, it is possible to establish that consumers commonly associate positively the social responsibility of small firms with their values, thereby allowing a greater intention to purchase the brand of products or services developed by these companies (Du et al., 2007). Thus, the various social responsibility activities that companies adopt and implement for the benefit of the community in which they are located, can have a greater impact on consumers' perception that their products or services are socially responsible and, with it, grant greater level of brand equity (Dacin \& Brown, 2002).

Likewise, Bhattacharya and Sen (2004) concluded that the values of consumers and their concept of social responsibility are closely linked to the CSR activities of companies, as consumers will be willing to pay a higher price for those brands of products or services that are perceived as socially responsible (Trudel \& Cotte, 2008). Du et al. (2007) obtained similar results, finding in their respective study that the values and identification of companies have a greater impact on the level of perception in consumers when companies develop social responsibility activities. Therefore, it is feasible to establish that the social responsibility activities that companies implement can be considered as the essence of the brand equity of their products or services (Wang \& Korschun, 2015). Thus, considering the information presented above, it is possible to propose the second research hypothesis.

\section{H2: The higher level of social responsibility, higher level of brand equity}

The ancestry of studies oriented in the analysis and discussion of CSR activities in companies worldwide, has allowed researchers and academics to try to understand and demonstrate the different reactions that consumers have in the brand of products or services of the companies, when incorporating the organizations activities of economic, social, and, especially, environmental responsibility (Du et al., 2011; Sen et al., 2016). However, CSR activities that companies adopt and implement, primarily small firms, will have to be part of their business strategies, which in turn must have a solid win-win basis for both consumers and society, as a whole, as for the companies themselves (Laughlin \& Ashan, 1994; Gupta \& Pirsch, 2006).

In addition, this important decision implies that the managers and/or owners of the firms will have to align, all those CSR activities that adopt and implement not only with the values of the organization, but also with the main environmental problems of the community or locality where they are located that the company is willing to support in its solution (Husted \& Allen, 2007; Beckmann, 2007; Guzman et al., 2008), This could improve consumers' perception of the brand equity of their products or services (Melo \& Galan, 2011). Therefore, it is possible to establish that the fundamental objective of firms, especially small ones, will be to identify the most appropriate ways for them to align environmental responsibility activities with the expectations of their consumers, in such a way that the value improves brand of your products (Guzman \& Becker-Olsen, 2010).

Likewise, the strategic approach of the various CSR activities that firms, primarily small ones, will develop will generate a greater commitment in the long term both with their main trading partners and with their investors, employees, consumers and society in general (Snider et al., 2003; Ingenbleek et al., 2007). Therefore, it is possible to establish that the responsibility and commitment that companies have with their business partners (Freeman, 1994), together with the adoption and implementation of environmental responsibility activities, will allow organizations not only to obtain significant growth in its level of growth and business profitability, derived from a higher level of consumer preference in the purchase of its products or services, but also the perception of a higher brand equity (Wang \& Korschun, 2015). Thus, considering the information presented above, it is possible to propose the third research hypothesis.

\section{H3: The higher level of environmental responsibility, higher level of brand equity}

\subsection{Sampling Procedures}

To respond to the research hypotheses raised in this paper, it was considered pertinent to carry out an empirical study in small firms in the State of Aguascalientes (Mexico), for which the business directory of the Mexican Business Information System for the state was used of Aguascalientes of the year 2017, in which there was a record as of January 30 of the same year 1,427 small companies with 5 to 250 employees. Likewise, a survey 
was designed to be answered by managers and/or owners of small firms, and a sample of 300 selected small firms was applied through a personal interview through a simple random sampling, with an error of the $\pm 5 \%$ and a level of significance of $95 \%$, which represented a little more than $21 \%$ of the total registered small businesses, and was applied during the months of February to April 2017.

\subsection{Measures and Covariates}

In addition, three dimensions were considered for the measurement of CSR activities: Economic Responsibility measured through a 9-item scale; Social Responsibility measured through a scale of 10 items and; Environmental responsibility measured by means of a 7-item scale, being adapted from the European Union (2001), Bloom and Gundlach (2001), Bigné et al. (2005) and Alvarado and Schlesinger (2008). Likewise, the scale adapted by Berthon et al. (2008) was used to measure the brand equity, based on the scale developed by Keller (2008), who considered that brand equity can be measured using a 5 -item scale. All items of the CSR and brand equity scales were measured through a 5 -point Likert-type scale with $1=$ completely disagree to $5=$ completely agree as limits.

Likewise, to confirm the reliability and validity of the two scales used, a Confirmatory Factor Analysis (CFA) was applied, using the maximum likelihood method with the EQS 6.2 software (Bentler, 2005; Brown, 2006; Byrne, 2006). Thus, reliability was measured by the Cronbach's alpha and the Composite Reliability Index (CRI) (Bagozzi \& Yi, 2011). The results obtained from the CFA are presented in Table 1 and show that the theoretical model analyzed has a good fit of the data $\left(\mathrm{S}-\mathrm{BX} \mathrm{X}^{2}=2,946,001 ; \mathrm{df}=397 ; \mathrm{p}=0.000 ; \mathrm{NFI}=0.849 ; \mathrm{NNFI}=0.889\right.$; CFI $=0.900$; RMSEA $=0.073$ ), obtaining values of Cronbach's alpha and CRI greater than 0.7 , which indicates the existence of reliability in the CSR and brand equity scales (Nunally \& Bernstein, 1994; Hair et al., 1995).

Table 1. Internal consistency and convergent validity of the theoretical model

\begin{tabular}{|c|c|c|c|c|c|c|}
\hline Variable & Indicator & $\begin{array}{l}\text { Factorial } \\
\text { Load }\end{array}$ & $\begin{array}{l}\text { Robust } \\
\text { Valor t }\end{array}$ & $\begin{array}{c}\text { Cronbach's } \\
\text { Alpha }\end{array}$ & CRI & RVI \\
\hline \multirow{7}{*}{ Economic Responsibility } & ECR1 & $0.624 * * *$ & $1.000^{\mathrm{a}}$ & \multirow{7}{*}{0.914} & \multirow{7}{*}{0.915} & \multirow{7}{*}{0.612} \\
\hline & ECR2 & $0.625 * * *$ & 14.581 & & & \\
\hline & ECR3 & $0.729 * * *$ & 12.349 & & & \\
\hline & ECR4 & $0.774 * * *$ & 11.158 & & & \\
\hline & ECR5 & $0.894 * * *$ & 12.353 & & & \\
\hline & ECR6 & $0.921 * * *$ & 12.584 & & & \\
\hline & ERC7 & $0.854 * * *$ & 11.979 & & & \\
\hline \multirow{12}{*}{ Social Responsibility } & SOR1 & $0.846^{* * *}$ & $1.000^{\mathrm{a}}$ & \multirow{12}{*}{0.968} & \multirow{12}{*}{0.969} & \multirow{12}{*}{0.722} \\
\hline & SOR2 & $0.853 * * *$ & 29.684 & & & \\
\hline & SOR3 & $0.766 * * *$ & 19.927 & & & \\
\hline & SOR4 & $0.763 * * *$ & 17.367 & & & \\
\hline & SOR5 & $0.777 * * *$ & 16.739 & & & \\
\hline & SOR6 & $0.792 * * *$ & 15.849 & & & \\
\hline & SOR7 & $0.821 * * *$ & 16.027 & & & \\
\hline & SOR8 & $0.854 * * *$ & 14.828 & & & \\
\hline & SOR9 & $0.917 * * *$ & 15.784 & & & \\
\hline & SOR10 & $0.951 * * *$ & 15.372 & & & \\
\hline & SOR11 & $0.918 * * *$ & 14.193 & & & \\
\hline & SOR12 & $0.912 * * *$ & 14.137 & & & \\
\hline \multirow{6}{*}{$\begin{array}{l}\text { Environmental } \\
\text { Responsibility }\end{array}$} & ENR1 & $0.628 * * *$ & $1.000^{\mathrm{a}}$ & \multirow{6}{*}{0.927} & \multirow{6}{*}{0.928} & \multirow{6}{*}{0.691} \\
\hline & ENR2 & $0.631 * * *$ & 13.827 & & & \\
\hline & ENR3 & $0.751 * * *$ & 10.923 & & & \\
\hline & ENR4 & $0.957 * * *$ & 9.781 & & & \\
\hline & ENR5 & $0.958 * * *$ & 10.208 & & & \\
\hline & ENR6 & $0.979 * * *$ & 9.892 & & & \\
\hline \multirow{5}{*}{ Brand Equity } & BEQ1 & $0.840 * * *$ & $1.000^{\mathrm{a}}$ & \multirow{5}{*}{0.898} & \multirow{5}{*}{0.899} & \multirow{5}{*}{0.641} \\
\hline & BEQ2 & $0.857 * * *$ & 22.160 & & & \\
\hline & BEQ3 & $0.838 * * *$ & 18.511 & & & \\
\hline & BEQ4 & $0.753 * * *$ & 16.731 & & & \\
\hline & BEQ5 & $0.704 * * *$ & 16.020 & & & \\
\hline$S-B X^{2}(\mathrm{df}=397)=$ & $46.001 ; \mathrm{p}<$ & $0 ; \mathrm{NFI}=0.8$ & $9 ; \mathrm{NNFI}=0$ & ; CFI = 0.900; & $\overline{\mathrm{SEA}}=0$ & \\
\hline
\end{tabular}


Similarly, the results of the CFA indicate that all the items of the related factors of the CSR scales and the brand equity are significant $(p<0.01)$, the value of all standardized factor loads is greater than 0.6 (Bagozzi \& Yi, 2011), and the Extract Variance Index (EVI) of each pair of constructs of the theoretical CSR model and brand equity, have a value greater than 0.5 (Fornell \& Larcker, 1981), which shows that said theoretical model has an excellent fit of the data, thereby demonstrating the existence of convergent validity.

Additionally, the discriminant validity of the theoretical CSR model and the brand equity was measured by means of two tests, which are presented in Table 2. First, the confidence interval test is presented (Anderson \& Gerbing, 1988), which establishes that with a $95 \%$ confidence interval, none of the individual elements of the latent factors of the correlation matrix has the value of 1 . Second, the extracted variance test is presented (Fornell \& Larcker, 1981), which states that the variance extracted from each pair of constructs is lower than its corresponding EVI. Therefore, according to the results obtained from the application of both tests, it is possible to conclude that both tests demonstrate sufficient evidence of the existence of discriminant validity.

The diagonal represents the Extracted Variance Index (EVI), whereas above the diagonal the variance is presented (squared correlation). Below diagonal, the estimated correlation of factors is presented with $95 \%$ confidence interval.

Table 2. Discriminant validity of the theoretical model

\begin{tabular}{ccccc}
\hline Variables & $\begin{array}{c}\text { Economic } \\
\text { Responsibility }\end{array}$ & Social Responsibility & $\begin{array}{c}\text { Environmental } \\
\text { Responsibility }\end{array}$ & Brand Equity \\
\hline Economic Responsibility & $\mathbf{0 . 6 1 2}$ & 0.128 & 0.154 & 0.110 \\
\hline Social Responsibility & $0.300-0.416$ & $\mathbf{0 . 7 2 2}$ & 0.129 & 0.066 \\
\hline $\begin{array}{c}\text { Environmental } \\
\text { Responsibility }\end{array}$ & $0.325-0.461$ & $0.301-0.417$ & $\mathbf{0 . 6 9 1}$ & 0.094 \\
\hline Brand Equity & $0.252-0.412$ & $0.199-0.315$ & $0.233-0.381$ & $\mathbf{0 . 6 4 1}$ \\
\hline
\end{tabular}

\section{Results}

To respond to the hypothesis raised in this empirical study, a model of structural equations was applied with the support of the EQS 6.2 software (Bentler, 2005; Byrne, 2006; Brown, 2006), analyzing the nomological validity of the theoretical CSR model and the brand equity through the Chi-square test, by means of which the results obtained between the theoretical model and the measurement model were compared, obtaining non-significant results which allows establishing an explanation of the observed relationships between the constructs latent (Anderson \& Gerbing, 1988; Hatcher, 1994). Table 3 shows in greater detail the results obtained from the application of the structural equation model.

Table 3. Results of the structural equation model of Family SMEs

\begin{tabular}{|c|c|c|c|}
\hline Hypothesis & Structural Relationship & $\begin{array}{r}\text { Standardized } \\
\text { Coefficient }\end{array}$ & $\begin{array}{l}\text { Robust T } \\
\text { Value }\end{array}$ \\
\hline $\begin{array}{l}\text { H1: The higher level of economic } \\
\text { responsibility, the higher level of brand } \\
\text { equity. }\end{array}$ & E.R. $\rightarrow \quad$ Brand Equity & $0.210 * * *$ & 4.134 \\
\hline $\begin{array}{l}\text { H2: The higher level of social responsibility, } \\
\text { the higher level of brand equity. }\end{array}$ & S.R. $\quad \rightarrow \quad$ Brand Equity & $0.367 * * *$ & 6.040 \\
\hline $\begin{array}{l}\text { H3: The higher level of environmental } \\
\text { responsibility, the higher level of brand } \\
\text { equity. }\end{array}$ & E.R. $\rightarrow$ Brand Equity & $0.319 * * *$ & 5.728 \\
\hline
\end{tabular}

Table 3 shows the results obtained from the application of the structural equation model, in which it can be observed that, with respect to hypothesis $\mathbf{H 1}$, the results obtained $(\beta=0.210, \mathrm{p}<0.01)$ indicate that economic responsibility has effects significant positive in the brand equity of the products or services of small firms. Regarding the $\mathbf{H 2}$ hypothesis, the results obtained $(\beta=0.367, \mathrm{p}<0.01)$ indicate that social responsibility also has significant positive effects on the brand equity of the products or services of small firms. With respect to hypothesis $\mathbf{H 3}$, the results obtained $(\beta=0.319, \mathrm{p}<0.01)$ indicate that environmental responsibility has significant positive effects on the brand equity of the products or services of small firms. Therefore, it is possible 
to establish that the various CSR activities that small firms adopt and implement will positively affect their level of brand equity.

\section{Discussion}

The results obtained in this empirical study allow us to conclude in three fundamental aspects. In the first place, the various actions carried out by small firms in order to improve their quality of life for their employees and workers, even though it is a topic well seen and appreciated by consumers and society in general. Therefore, it is possible to conclude that the activities of economic responsibility that have been implemented by small firms, both inside and outside the organization, are not enough to significantly improve the quality of life of its staff, much less for the support of philanthropic activities of the community society or locality where they are located, which can generate not only a reduction in their growth and business performance, but also a low level of perception by their consumers of brand equity.

Second, the various social responsibility activities that small firms have adopted and implemented generally revolve around charitable and social altruism actions, as well as their direct participation in most cultural and religious events that take place in the community or locality where they are established, which allows the values and beliefs of the organization to be shared with society in general. Therefore, it can be concluded that the social responsibility activities that small firms have developed have achieved a significant positive impact not only on the recognition and identification by society as socially responsible companies, but also that their values and beliefs are similar to those of the community, which allows consumers to have a higher level of perception of the brand equity of their products or services.

Thirdly, the activities carried out by small firms in the care of the environment of the community or locality where they are installed, is an issue that is well seen by a considerable percentage of citizens, which leads society to prefer the purchase of their products or services than those of their main competitors, precisely because of the commitment that small firms have to carry out actions aimed at caring for the environment. Therefore, it is possible to conclude that the various environmental responsibility activities that small firms have adopted and implemented have achieved a significant positive impact on the inhabitants of the communities or localities where they are located, which can be translated not only into recognition by society as a socially responsible company, but also at a higher level of perception by its consumers of the brand equity of its products or services.

In this context, it can be concluded in general that if consumers of the products or services generated by small firms, perceive that companies are developing actions that lead to the fulfillment of their corporate social responsibility, then they will not only be willing to prefer purchase of the brand of its products or services, but also to carry out a word of mouth promotion with all its acquaintances in favor of the acquisition of the brand of these products or services, which will allow companies not only to obtain a higher level of the brand equity of its products or services, but also a significant growth in its level of sales, growth and business performance and, as a result, more and better competitive advantages compared to its main competitors.

Additionally, the results obtained in this empirical study also have a series of implications that are important to highlight, the first being the reference that there are relatively few small firms that publish or disclose their clients and consumers, the various actions of social and economic support and environmental care that they perform for the benefit of the community or locality where they are located. Therefore, an important part of its customers and consumers are unaware of these types of activities. Therefore, small firms executives have to design and implement an advertising program that allows them to inform their main customers and consumers, the various social actions and activities that the organization performs for the benefit of society in general.

A second implication of these results is that the managers of small firms, have to consider that in the various social, environmental and economic actions and activities that they carry out for the benefit of their staff and society in general, the brand equity of their products or services is essential, as consumers will be able to identify the brand of their products or services and will have a greater preference in the consumption of such products or services. Therefore, managers not only have to advertise the social responsibility activities they carry out, but also all brands of their products or services, precisely so that their customers and consumers associate these brands with the social responsibility actions generated.

A third implication derived from these results is that the managers of small firms, not only have to consider social responsibility activities as another strategy of the organization, but rather as part of their daily activities that all have to be carried out the days to obtain better business results, since the various social responsibility actions require the commitment not only of the managers, but also of the workers and employees of the organization, because the actions and activities carried out by the company's staff inside and outside the organization, will have an effect not only on the level of perception by customers and consumers about the 
company's social responsibility, but also on the brand of the products or services generated by small firms.

A fourth and final implication of the results previously obtained is that the managers of small firms have to design and implement all those formal and informal training programs, both for managers and for employees and workers, that allow all personnel be clear about the implications of being recognized, by your customers and consumers as a socially responsible company, since it will be essential that both managers and staff of the organization, recognize which of the various actions and activities carried out by the organization, have greater effects not only on the significant increase in the perception of its customers and consumers as a socially responsible company, but also that all brands of products or services of companies are identified and associated with social responsibility.

On the other hand, this empirical study also has several limitations that are relevant to determine, the first one being related to the sample that was used, since only those small firms that had registered between 5 and 250 employees were considered at the time of the application of the survey, so in future studies it would be relevant to consider in the sample all small firms that have less than 5 employees to corroborate the results obtained. A second limitation is that the information collection instrument (survey) was applied only to managers and/or owners of small firms in the state of Aguascalientes (Mexico), so in future studies it would be essential that this same instrument of apply to small firms in other states of the country to corroborate the results obtained.

A third limitation is that only qualitative variables were considered for the measurement of corporate social responsibility and brand equity, for which it is future studies it would be pertinent to consider the hard data or quantitative variables of small firms, which allow corroborating the existence or not of significant differences in the results obtained. A fourth and final limitation is that the instrument for collecting information (survey) was applied only to managers and/or owners of small firms, so it was assumed that these managers have extensive knowledge of the various social responsibility activities and brand equity carried out by your company, so in future studies it will be necessary to apply this same instrument to a different sample to corroborate whether the results differ or not from those obtained.

\section{References}

Aaker, D. A. (1991). Managing Brand Equity: Capitalizing on the Value of Brand Name. New York, NY: Free Press.

Aaker, D. A., \& Joachimsthaler, E. (2000). The brand relationship spectrum: The key to brand architecture challenge. California Management Review, 42(4), 8-23. https://doi.org/10.1177/000812560004200401

Alvarado, H., \& Schlesinger, M. (2008). Dimensionalidad de la responsabilidad social empresarial percibida y sus efectos sobre la imagen y la reputación: Una aproximación desde el modelo de Carroll. Estudios Gerenciales, 24(108), 37-59. https://doi.org/10.1016/S0123-5923(08)70043-3

Anderson, J., \& Gerbing, D. (1988). Structural equation modeling in practice: a review and recommended two-step approach. Psychological Bulletin, 13, 411-423. https://doi.org/10.1037/0033-2909.103.3.411

Baalbaki, S., \& Guzman, F. (2016). A consumer perceived consumer-based brand equity. Journal of Brand Management, 23(3), 229-251. https://doi.org/10.1057/bm.2016.11

Bagozzi, R. P., \& Yi, Y. (2011). Specification, evaluation and interpretation of structural equation models. Journal of the Academy of Marketing Science, 40(4), 8-34. https://doi.org/10.1007/s11747-011-0278-x

Bass, F. M., \& Wilkie, W. L. (1973). A comparative analysis of attitudinal predictions of brand preference. Journal of Marketing Research, 10(3), 262-269. https://doi.org/10.1177/002224377301000306

Beckmann, S. C. (2007). Consumers and corporate social responsibility: Matching the unmatchable? Australasian Marketing Journal, 15(1), 27-36. https://doi.org/10.1016/S1441-3582(07)70026-5

Bentler, P. (2005). EQS 6 Structural Equations Program Manual. Encino, CA: Multivariate Software.

Berger, I. E., Cunningham, P. H., \& Drumwright, M. E. (2007). Mainstreaming corporate social responsibility: Developing markets for virtue. California Management Review, 49(4), 132-157. https://doi.org/10.2307/41166409

Berthon, P. R., Pitt, L., \& Campbell, C. (2008). Ad lib: When customers create the ad. California Management Review, 50(4), 6-31. https://doi.org/10.2307/41166454

Bhattacharya, C. B., \& Sen, S. (2003). Consumer-company identification: A framework for understanding consumers' relationship with companies. Journal of Marketing, 67(2), 76-88.

https://doi.org/10.1509/jmkg.67.2.76.18609 
Bhattacharya, C. B., \& Sen, S. (2004). Doing better at doing good: When, why, and how consumers respond to corporate social initiatives. California Management Review, 47(1), 9-24. https://doi.org/10.2307/41166284

Bigné, A. E., Andreu, L., \& Sánchez, G. I. (2005). Investigación en marketing turístico: Un análisis de las publicaciones en el período 1995-2003. XV Jornadas Hispano-Lusas de Gestión Científica, Sevilla.

Bigné, A. E., Currás-Pérez, R., \& Aldás-Manzano, J. (2012). Dual nature of cause-brand fit: Influence on corporate social responsibility consumer perception. European Journal of Marketing, 46(3/4), 575-594. https://doi.org/10.1108/03090561211202620

Bigné, A. E., Currás-Pérez, R., \& Sánchez-García, I. (2009). Brand credibility in cause-related marketing: The moderating role of consumer values. Journal of Product \& Brand Management, 18(6), 437-447. https://doi.org/10.1108/10610420910989758

Bloom, P., \& Gundlach, G. (2001). Handbook of Marketing and Society. Thousand Oaks, CA: Sage Publications. https://doi.org/10.4135/9781452204765

Brown, T. (2006). Confirmatory Factor Analysis for Applied Research. New York, NY: The Guilford Press.

Byrne, B. (2006). Structural Equation Modeling With EQS, Basic Concepts, Applications, and Programming (2nd ed.). London; LEA Publishers.

Chappell, T. (1993). The Soul of a Business: Managing for Profit and the Common Good. Des Plaines, IL: Bantam.

Chatzipanagiotou, K., Veloutsou, C., \& Christodoulides, G. (2016). Decoding the complexity of the consumer-based brand equity process. Journal of Business Research, 69(11), 5479-5486. https://doi.org/10.1016/j.jbusres.2016.04.159

Cifci, S., Ekinci, Y., Whyatt, G., Japutra, A., Milinillo, S., \& Siala, H. (2016). A cross validation of consumer-based brand equity models: Driving customer equity in retail brands. Journal of Business Research, 69(9), 3740-3747. https://doi.org/10.1016/j.jbusres.2015.12.066

Dacin, P. A., \& Brown, T. J. (2002). Corporate identity and corporate associations: A framework for future research. Corporate Reputation Review, 5(2/3), 254-263. https://doi.org/10.1057/palgrave.crr.1540178

Daft, R. L. (2003). Organization Theory and Design. Cincinnati: South-Western College Publishing.

Du, S., Bhattacharya, C. B., \& Sen, S. (2007). Reaping relational rewards from corporate social responsibility: The role of competitive positioning. International Journal of Research in Marketing, 24(3), 224-241. https://doi.org/10.1016/j.jiresmar.2007.01.001

Du, S., Bhattacharya, C. B., \& Sen, S. (2011). Corporate social responsibility and competitive advantage: Overcoming the trust barrier. Management Science, 57(1), 1528-1545. https://doi.org/10.1287/mnsc.1110.1403

Ellen, P. S., Webb, D. J., \& Mohr, L. A. (2006). Building corporate associations. Consumer attributes for corporate socially responsible programs. Journal of the Academy of Marketing Science, 34(2), 147-157. https://doi.org/10.1177/0092070305284976

European Union. (2001). Libro verde, promuovere un quadro europeo per la responsabilità sociale delle imprese. Green Paper. Retrieved from http://www.europea.eu.int

Ferrell, O. C., \& Geoffrey, H. (2000). Business: A Changing World. New York, NY: McGraw-Hill.

Fornell, C., \& Larcker, D. (1981). Evaluating structural equation models with unobservable variables and measurement error. Journal of Marketing Research, 18, 39-50. https://doi.org/10.1177/002224378101800104

Freeman, R. E. (1994). The politics of stakeholder theory: Some future directions. Business Ethics Quarterly, 4(4), 409-421. https://doi.org/10.2307/3857340

Grönroos, C., \& Voima, P. (2013). Critical service logic: Making sense of value creation and co-creation. Journal of the Academy of Marketing Science, 41(2), 133-150. https://doi.org/10.1007/s11747-012-0308-3

Gupta, S., \& Pirsch, J. (2006). A taxonomy of cause-related marketing research: Current findings and future research directions. Journal of Nonprofit \& Public Sector Marketing, 15(1/2), 25-43. https://doi.org/10.1300/J054v15n01_02

Guzman, F., \& Becker-Olsen, K. L. (2010). Strategic corporate social responsibility: A brand-building tool. In 
Louche, C., Idowu, S. O., \& Filho, W. L. (Eds.), Innovative Corporate Social Responsibility: From Risk Management to Value Creation (pp. 196-219). Sheffield: Greenleaf Publishing. https://doi.org/10.9774/GLEAF.978-1-907643-26-2_11

Guzman, F., Becker-Olsen, K. L., \& Hill, R. P. (2008). Desarrollar un programa de RSC a la manera correcta. Harvard Business Review America Latina, 86(4), 42-49.

Guzman, G., \& Davis, D. (2017). The impact of corporate social responsibility on brand equity: Consumer responses to two types of fit. Journal of Product \& Brand Management, 26(5), 435-446. https://doi.org/10.1108/JPBM-06-2015-0917

Gyrd-Jones, R. I., \& Kornum, N. (2013). Managing the co-created brand: Value and cultural complementarity in online and offline multi-stakeholders ecosystems. Journal of Business Research, 66(9), 1484-1493. https://doi.org/10.1016/j.jbusres.2012.02.045

Hair, J. F., Anderson, R. E., Tatham, R. L., \& Black, W. C. (1995). Multivariate Data Analysis with Readings. New York, NY: Prentice-Hall.

Hamlin, R. P., \& Wilson, T. (2004). The impact of cause branding on consumer reactions to products: Does product/cause fit really matter? Journal of Marketing Management, 20(7/8), 663-681. https://doi.org/10.1362/0267257041838746

Hatcher, L. (1994). A Step by Step Approach to Using the SAS System for Factor Analysis and Structural Equation Modeling. Cary, NC: SAS Institute Inc.

Husted, B. W., \& Allen, D. B. (2007). Corporate social strategy in multinational enterprises: Antecedents and value creation. Journal of Business Ethics, 74(4), 345-361. https://doi.org/10.1007/s10551-007-9511-4

Iglesias, O., Ind, N., \& Alfaro, M. (2013). The organic view of the brand: A brand value co-creation model. Journal of Brand Management, 20(8), 670-688. https://doi.org/10.1057/bm.2013.8

Ingenbleek, P., Binnekamp, M., \& Goddijn, S. (2007). Setting standards for CSR: A comparative case study on criteria-formulating organizations. Journal of Business Research, 60(5), 539-548. https://doi.org/10.1016/j.jbusres.2007.01.004

Keller, K. L. (2008). Strategic Brand Management: Building, Measuring, and Managing Brand Equity (3rd ed.). Upper Saddle River, NJ: Pearson Prentice-Hall.

Keller, K. L., \& Lehmann, D. R. (2006). Brands and branding: Research findings and future priorities. Marketing Science, 25(6), 740-759. https://doi.org/10.1287/mksc.1050.0153

Kennedy, E., \& Guzman, F. (2016). Co-creation of brand identities: Consumer and industry influence and motivations. Journal of Consumer Marketing, 33(5), 313-323. https://doi.org/10.1108/JCM-07-2015-1500

Kim, J. E., \& Johnson, K. K. P. (2013). The impact of moral emotions on cause-related marketing campaigns: A cross-cultural examination. Journal of Business Ethics, 112(1), 79-90.

https://doi.org/10.1007/s10551-012-1233-6

Kotler, P., \& Armstrong, G. (2010). Principles of Marketing. New Jersey, NJ: Pearson Education.

Kotler, P., \& Lee, N. (2004). Corporate Social Responsibility: Doing the Most Good for your Company and your Cause. New York, NY: John Willey \& Sons.

Laczniak, G., \& Murphy, P. (1991). Fostering ethical marketing decisions. Journal of Business Ethics, 10(4), 259-271. https://doi.org/10.1007/BF00382965

Lafferty, B. A. (2007). The relevance of fit in a cause-brand alliance when consumers evaluate corporate credibility. Journal of Business Research, 60(5), 447-453. https://doi.org/10.1016/j.jbusres.2006.09.030

Laughlin, J. L., \& Ashan, M. B. (1994). A strategic model of multinational corporation social responsibility in the third world. Journal of International Marketing, 2(3), 101-115. https://doi.org/10.1177/1069031X9400200306

Lichtenstein, D. R., Drumwright, M. E., \& Braig, M. B. (2004). The effect of corporate social responsibility on customer donations to corporate-supported nonprofits. Journal of Marketing, 68(4), 16-32. https://doi.org/10.1509/jmkg.68.4.16.42726

Liu, C. T., Guo, Y. M., \& Lee, C. H. (2011). The effects of relationship quality and switching barriers on customer loyalty. International Journal of Information Management, 31(1), 71-79. https://doi.org/10.1016/j.ijinfomgt.2010.05.008 
Lussier, R. N. (2000). Management Fundamentals. New York, NY: Thomson Learning Inc.

Maignan, I., Ferrell, O. C., \& Ferrell, L. (2005). A stakeholder model for implementing social responsibility in marketing. European Journal of Marketing, 39(9/10), 956-977. https://doi.org/10.1108/03090560510610662

Malhotra, N. K., \& Agarwal, J. (2017). Ethics and morality in consumer-brand relationships. Journal of Business Research, (Special Issue), 1-11.

Melo, T., \& Galan, J. I. (2011). Effects of corporate social responsibility on brand value. Journal of Brand Management, 18(6), 423-437. https://doi.org/10.1057/bm.2010.54

Moosmayer, D. C., \& Fuljahn, A. (2013). Corporate motive and fit in cause related marketing. Journal of Product \& Brand Management, 22(3), 200-207. https://doi.org/10.1108/JPBM-04-2012-0125

Nan, X., \& Heo, K. (2007). Consumer responses to corporate social responsibility (CSR) initiatives: Examining the role of brand-cause fit in cause-related marketing. Journal of Advertising, 36(2), 63-74. https://doi.org/10.2753/JOA0091-3367360204

Nunally, J. C., \& Bernstein, I. H. (1994). Psychometric Theory (3rd ed.). New York, NY: McGraw-Hill.

Oliver, R. L. (1999). Whence consumer loyalty? Journal of Marketing, 63(1), 33-44. https://doi.org/10.1177/00222429990634s105

Orel, F. D., \& Kara, A. (2014). Supermarket self-checkout service quality, customer satisfaction, and loyalty: Empirical evidence from an emerging market. Journal of Retailing and Customer Services, 21(2), 118-129. https://doi.org/10.1016/j.jretconser.2013.07.002

Park, E., Joon, K. K., \& Jib, K. S. (2017). Corporate social responsibility as a determinant of consumer loyalty: An examination of ethical standard, satisfaction, and trust. Journal of Business Research, 76(1), 8-13. https://doi.org/10.1016/j.jbusres.2017.02.017

Peloza, J., \& Shang, J. (2011). How can corporate social responsibility activities create value for stakeholders? A systematic review. Journal of the Academy of Marketing Science, 39(1), 117-135. https://doi.org/10.1007/s11747-010-0213-6

Pérez, A., \& Rodríguez del Bosque, I. (2015). Customer responses to the CSR of banking companies. Journal of Product \& Brand Management, 24(5), 481-493. https://doi.org/10.1108/JPBM-12-2014-0759

Porter, M. E., \& Kramer, M. R. (2006). Strategy \& society: The link between competitive advantage and corporate social responsibility. Harvard Business Review, 84(12), 78-92.

Pracejus, J. W., \& Olsen, G. D. (2004). The role of brand/cause fit in the effectiveness of cause-related marketing companies. Journal of Business Research, 57(6), 635-640. https://doi.org/10.1016/S0148-2963(02)00306-5

Preston, L. E., \& O'Bannon, D. P. (1997). The corporate social-financial performance relationship: A typology and analysis. Business and Society, 36(4), 419-429. https://doi.org/10.1177/000765039703600406

Romani, S., \& Grappi, S. (2014). How companies' good deeds encourage consumers to adopt pro-social behaviour. European Journal of Marketing, 48(1), 943-963. https://doi.org/10.1108/EJM-06-2012-0364

Romani, S., Grappi, S., \& Bagozzi, R. P. (2013). Explaining consumer reactions to corporate social responsibility: The role of gratitude and altruistic values. Journal of Business Ethics, 114(2), 193-206. https://doi.org/10.1007/s10551-012-1337-z

Samu, S., \& Wymer, W. (2014). Cause marketing communications: Consumer interface on attitudes towards brand and cause. European Journal of Marketing, 48(7/8), 1333-1353. https://doi.org/10.1108/EJM-04-2012-0226

Sen, S., \& Bhattacharya, C. B. (2001). Does doing good always lead to doing better? Consumer reactions to corporate social responsibility. Journal of Marketing Research, 38(2), 225-243. https://doi.org/10.1509/jmkr.38.2.225.18838

Sen, S., Bhattacharya, C. B., \& Korschun, D. (2006). The role of corporate social responsibility in strengthening multiple stakeholder relationships: A field experiment. Journal of the Academy of Marketing Science, 34(2), 158-166. https://doi.org/10.1177/0092070305284978

Sen, S., Du, S., \& Bhattacharya, C. B. (2016). Corporate social responsibility: A consumer psychology perspective. Current Opinion in Psychology, 10(1), 70-75. https://doi.org/10.1016/j.copsyc.2015.12.014 
Sims, R. L., \& Kroeck, K. G. (1994). The influence of ethics fit on employee satisfaction: Commitment and turnover. Journal of Business Ethics, 10(4), 259-271.

Snider, J., Hill, R. P., \& Martin, D. (2003). Corporate social responsibility in the $21^{\text {st }}$ century: A view from the world's most successful firms. Journal of Business Ethics, 48(2), 175-187. https://doi.org/10.1023/B:BUSI.0000004606.29523.db

Stanaland, A. J., Lwin, M. O., \& Murphy, P. E. (2011). Consumer perceptions of the antecedents and consequences of corporate social responsibility. Journal of Business Ethics, 102(1), 47-55. https://doi.org/10.1007/s10551-011-0904-z

Tornelli, C. J., Monga, A. B., \& Kaikati, A. M. (2012). Doing poorly by doing good: Corporate social responsibility and brand concepts. Journal of Consumer Research, 38(5), 948-963. https://doi.org/10.1086/660851

Torres, A., Bijmolt, T. H., Tribó, J. A., \& Verhoef, P. (2012). Generating global brand equity through corporate social responsibility to key stakeholders. International Journal of Research in Marketing, 29(1), 13-24. https://doi.org/10.1016/j.ijresmar.2011.10.002

Trudel, R., \& Cotte, J. (2008). Corporate reputation: Does being ethical pay? Companies spend huge amount of money to be social responsible. Do consumers reward them for it? And how much? Wall Street Journal, 12 May, R4.

Turban, D. B., \& Greening, D. W. (1997). Corporate social performance and organizational attractiveness to prospective employees. Academy of Management Journal, 40(3), 658-672. https://doi.org/10.2307/257057

Vallester, C., \& von Wallpach, S. (2013). An online discursive inquiry into the social dynamics of multi-stakeholder brand meaning co-creation. Journal of Business Research, 66(9), 1505-1515. https://doi.org/10.1016/j.jbusres.2012.09.012

Vitell, S. J., King, R. A., Howie, K., Toti, J. F., Albert, L., Hidalgo, E. R., \& Yacout, O. (2016). Spirituality, moral identity, and consumer ethics: A multi-cultural study. Journal of Business Ethics, 139(1), 147-160. https://doi.org/10.1007/s10551-015-2626-0

Vogel, D. (2004). Is there a market for virtue? A critical appraisal of corporate social responsibility. Manuscript presented at the Third Transatlantic Business Ethics Conference.

Wang, W., \& Korschun, D. (2015). Spillover of social responsibility associations in a brand portfolio. Journal of Product \& Brand Management, 24(6), 596-609. https://doi.org/10.1108/JPBM-06-2014-0629

Xie, C., Bagozzi, R. P., \& Gronhaug, K. (2015). The role of moral emotions and individual differences in consumer responses to corporate green and non-green actions. Journal of the Academy of Marketing Science, 43(1), 333-356. https://doi.org/10.1007/s11747-014-0394-5

Xie, C., Bagozzi, R. P., \& Gronhaug, K. (2019). The impact of corporate social responsibility on consumer brand advocacy: The role of moral emotions, attitudes, and individual differences. Journal of Business Research, 95(1), 514-530. https://doi.org/10.1016/j.jbusres.2018.07.043

\section{Copyrights}

Copyright for this article is retained by the author(s), with first publication rights granted to the journal.

This is an open-access article distributed under the terms and conditions of the Creative Commons Attribution license (http://creativecommons.org/licenses/by/4.0/). 